\title{
Формування мотиваційно-особистісного компонента готовності магістрів до забезпечення якості освітнього процесу в закладі дошкільної освіти
}

\author{
Л. П. Загородня
}

Глухівський національний педагогічний університет імені Олександра Довженка

Corresponding author. E-mail: 1.zagorodnya69@gmail.com, ORCID: 0000-0002-2217-1041

Paper received 23.03.19; Accepted for publication 05.04.19.

\section{https://doi.org/10.31174/SEND-PP2019-196VII78-12}

\begin{abstract}
Анотація. У статті представлено результати дослідження стану сформованості мотиваційно-особистісного компонента готовності магістрів до забезпечення якості освітнього процесу в закладі дошкільної освіти на констатувальному та контрольному етапах експерименту. Коротко схарактеризовано формування означеного складника готовності в процесі вивчення авторського інтегрованого курсу «Методика забезпечення якості освітнього процесу в закладі дошкільної освіти».

Ключові слова: магістри дочкільної освіти, мотиваиійно-особистісний компонент готовності до забезпечення якості освітнього процесу в закладах дошкільної освіти, методи діагностики, авторський інтегрований курс, рівні сформованосmi.
\end{abstract}

Вступ. Проблема якості української освіти є актуальною. Свроінтеграційні процеси стимулюють зміни в освітніх стандартах, технологіях підготовки конкурентоспроможних педагогів-професіоналів. Рівень розвитку, освіченості і вихованості дитини дошкільного віку залежить від якості організації освітнього процесу в дошкільній установі, відповідальність за яку несе директор закладу. Готовність майбутнього керівника до забезпечення якості освітнього процесу в дошкільній установі - полікомпонентна, складноструктурована особистісна характеристика фахівця, в якій системотвірним елементом $є$ мотиваційноособистісний складник.

Короткий огляд публікацій 3 теми. Підготовка менеджерів для освітніх закладів є об'єктом вивчення В. Береки, С. Вітвицької, В. Жигірь, Л. ЗадорожноїКнягницької, Г. Закорченної, Г. Сльнікової, С. Калашнікової, В. Лунячека, О. Сакалюк, О. Слободянюк та інших науковців. Наукові розвідки, присвячені підготовці керівників для закладів дошкільної освіти належать Г. Закорченній, Г. Кравченко, Ю. Манилюк, Т. Пономаренко, О. Усик, Р. Шаповалу, А. Яцинік та іншим ученими.

Проте проблема підготовки керівників для закладів дошкільної освіти, зокрема формування їх готовності до забезпечення якості освітнього процесу грунтовно не досліджена.

Метою статті є висвітлення емпіричного дослідження рівнів мотиваційно-особистісного компонента означеної готовності майбутніх директорів ЗДО та процесу їі формування.

Матеріали та методи. Матеріалами вивчення проблематики формування готовності магістрів до забезпечення якості освітнього процесу виступають дисертації, автореферати дисертацій, монографії, статті в наукових виданнях. Дослідження було проведене із застосуванням теоретичних методів і прийомів пізнання (аналізу, синтезу, узагальнення, класифікації та систематизації теоретичних даних) та емпіричних методів (анкетування, оцінювання складників досліджуваної якості, методів математичної статистики), педагогічного експерименту (розробки й реалізації спеціального інтегрованого курсу).

Результати та їх обговорення. У контексті нашого дослідження, зокрема теми статті, на особливу увагу заслуговують праці Г. Закорченної [4], С. Вітвицької [1], В. Жигірь [5], Л. Задорожної-Княгницької [3].

Підготовка до педагогічного менеджменту в дошкільній освіті, як зазначає Г. Закорченна, найбільш ефективно здійснюється у спеціально організованих умовах навчання, що концентрують пізнавальну активність майбутніх фахівців в єдності трьох аспектів: змістового, операційного, ціннісного [4, с. 19].

У професіограмі, розробленій С. Вітвицькою, на увагу заслуговує цільовий компонент, в якому відображено вимоги до спрямованості фахівця, зокрема його потягів, бажань, інтересів, потреб, схильностей, ідеалів, світогляду, переконань [1, с. 30].

Л. Задорожна-Княгницька розглядає деонтологічну компетентність менеджера освіти як динамічну комбінацію деонтологічних знань, умінь і практичних навичок, способів мислення, професійних, світоглядних і громадянських якостей, деонтологічних цінностей, яка визначає здатність особи здійснювати належну професійну поведінку й виконувати професійний обов'язок [3, с. 26]. Першим, вагомим, компонентом в ii структурі вчена виокремлює мотиваційноціннісний, який характеризується наявністю професійної спрямованості на здійснення нормативної поведінки, стійкої позитивної мотивації керівника як носія професійно-моральних цінностей, усвідомленням значущості питань управлінської деонтології у власній професійній діяльності, сформованістю деонтологічно значущих якостей, наявністю адекватної самооцінки, самоактуалізації, сформованістю досвіду емоційно-ціннісних відносин, особистісних ставлень і орієнтацій [3, с. 27].

В. Жигірь виділяє два складники в професійній підготовці менеджерів освіти - професійний і особистісний, які тісно між собою пов'язані та ефективно формуватися можуть лише в комплексі [5, с. 114].

Беручи до уваги аналіз досліджень 3 підготовки менеджерів освіти, і дошкільної зокрема, ми виділили такі компоненти готовності магістрів до забезпечення якості освітнього процесу (ГДЗЯОП) в закладі дошкільної освіти: мотиваційно-особистісний, когнітивнопошуковий, діяльнісно-операційний, рефлексивнооцінний.

Мотиваційно-особистіний компонент у структурі ГДЗяОП магістрів, на наше переконання, є системот- 
вірним, оскільки надає процесу оволодіння професійними знаннями і вміннями усвідомленості і цілеспрямованості.

Для з'ясування стану сформованості мотиваційноособистісного компонента ГДЗЯОП у магістрантів спеціальності 012 «Дошкільна освіта», ми провели експеримент на базі шести українських закладів вищої освіти, а саме: Глухівського національного педагогічного університету імені Олександра Довженка, Маріупольського державного університету, Бердянського державного педагогічного університету, ДВНЗ «Донбаського державного педагогічного університету», Рівненського державного педагогічного університету, Полтавського національного педагогічного університету ім. В. Г. Короленка. Всього в експерименті взяли участь 544 магістранти денної і заочної форм навчання, а саме: 270 осіб контрольної групи i 274 особи експериментальної групи.

Процедура діагностики передбачала використання методик вивчення мотивації професійної діяльності (К. Замфір в модифікації А. Реана, Н. Бадмаєвої), визначення Я-концепції (методика Кемпбелла SCC); визначення місця компонентів ГДЗЯОП в ЗДО в іï структурі; анкетування, методів математичної статистики. При цьому ми орієнтувалися на визначені нами компоненти, критерії і показники ГДЗЯОП [2].

Професійна мотивація магістрів, на наше переконання, виступає внутрішньою рушійною силою розвитку професіоналізму i, зокрема, набуття ними ГДЗЯОП у ЗДО. Щодо мотивації професійної діяльності, то ми вважаємо оптимальним такий баланс мотивів: $\mathrm{BM}>3 П \mathrm{M}>3 \mathrm{HM}$ та $\mathrm{BM}=3 \Pi \mathrm{M}>3 \mathrm{HM}$, в якому внутрішня мотивація (ВМ) рівна зовнішній позитивній мотивації (ЗПМ) або вища за неї та за зовнішню негативну мотивацію (ЗНМ), а зовнішня негативна мотивація низька і наближена до одиниці. Аналіз бланків опитувальників засвідчив, що в $52 \%$ респондентів високий рівень мотивації професійної діяльності, у $26 \%$ - достатній, у $9 \%$ - середній і в $13 \%$ - низький.

$70 \%$ респондентів не змогли правильно визначити місце мотивації, як складника професійної спрямованості в структурі ГДЗЯОП.

Я-концепція (Self-concept) - загальний паттерн або конфігурація самосприйняття: концепція людини про те, якою вона $є$ [6, с. 609]. Для майбутнього директоpa, який підготовлений до забезпечення якості освітнього процесу в ЗДО, на наш погляд, необхідно мати високу і середню, наближену до високої, ясність Яконцепції. Проте, аналіз бланків опитування магістрантів засвідчив, що високої ясності Я-концепції не виявлено в жодного респондента, $41 \%$ магістрантів засвідчили середню ясність Я-концепції, наближену до високої, 35 \% - середню ясність Я-концепції і ще $24 \%$ - середню ясність Я-концепції, наближену до низької. Ці дані підтверджують достатній і середній рівень сформованості Я-концепції.

Анкетування було спрямоване на виявлення в магістрантів мотивів отримання другого вищого рівня освіти за спеціальністю 012 «Дошкільна освіта» i уявлень про складники професійної спрямованості на забезпечення якості освітнього процесу в установі (мотиви, ціннісні орієнтації, професійні потреби то- що), особистісні і професійні якості, необхідні для забезпечення якості освітнього процесу.

Аналіз відповідей магістрантів на питання анкети дозволяє зробити такі основні висновки: 1) переважаючим мотивом вступу до магістратури є отримання нових знань у галузі дошкільної освіти і професійне вдосконалення $(32 \%) ; 2)$ серед названих мотивів не виявили таких, які були б безпосередньо спрямовані на забезпечення якості освітнього процесу в закладах дошкільної освіти; 3) правильно серед складників професійної спрямованості директора закладу дошкільної освіти на забезпечення якості освітнього процесу в установі виокремлювали мотиви, потреби, ціннісні орієнтації, інтереси, ідеали - лише $10 \%$ респондентів; 4) $10 \%$ магістрантів денної форми і $27 \%$ заочної форми навчання назвали мотиви професійної діяльності, які стосуються забезпечення якості освітнього процесу в ЗДО, а саме: сприяння професійному росту членів педагогічного колективу, самоосвіта директора в галузі управління ЗДО, вдосконалення управлінських умінь щодо організації освітнього процесу в дошкільній установі, забезпечення дітей якісною освітою, покращення матеріальної бази; 5) 6 \% респондентів, які мають досвід роботи за фахом, назвали ціннісні орієнтації, які визначають спрямованість директора на забезпечення деяких умов організації освітнього процесу, зокрема орієнтація на зміцнення здоров'я дітей, на професійний ріст педагогічного колективу, покращення матеріальної бази ЗДО; 6) серед професійних потреб майбутніх директорів ЗДО, що визначають спрямованість на забезпечення якості освітнього процесу в установі, магістранти найчастіше називали загальні професійні потреби, проте жодна відповідь не була точною і вичерпною щодо професійних потреб директора, який прагне і може забезпечити якість освітнього процесу в дошкільній установі; 7) до особистісних якостей, які необхідні директору для забезпечення якості освітнього процесу в ЗДО, $85 \%$ магістрантів відносили моральні і $15 \%$ - інтелектуальні.

Узагальнивши дані всіх діагностичних методів та оцінивши їх за п'ятибальною системою, ми отримали результати, які дозволяють стверджувати, що в більшості майбутніх магістрів (52,9\% в експериментальній групі і 50\% - у контрольній групі) наявний середній рівень сформованості мотиваційно-особистісного компонента готовності до забезпечення якості освітнього процесу в закладі дошкільної освіти. Такі результати засвідчували необхідність проведення роботи 3 підвищення рівня означеного складника ГДЗяОП.

Ми усвідомлювали, що вплинути кардинально на Я-концепцію i професійну мотивацію магістрантів дуже складно, проте закцентувати їхню увагу на складниках спрямованості на забезпечення якості освітнього процесу в ЗДО, професійно-особистісних якостях керівника можливо. Варто зазначити, що формування системотвірного компонента ГДЗяОП відбувалося в комплексі з усіма іншими (когнітивнопошуковим, діяльнісно-операційним, рефлексивнооцінним), передусім у процесі реалізації авторського інтегративного курсу «Методика забезпечення якості освітнього процесу в ЗДО». Серед низки завдань дис- 
ципліни особливу увагу приділяли формуванню мотивації до цілеспрямованого забезпечення якості освітнього процесу в ЗДО, постійного професійного і особистісного самовдосконалення в галузі дошкільної освіти. На мотивацію майбутніх директорів впливали через формування когнітивно-пошукового складника готовності. Ми передбачали, що чим більше магістранти дізнаватимуться про сутність, механізми, засоби, умови забезпечення якості освітнього процесу в ЗДО, тим більшим буде усвідомлення ними мотивів, ціннісних орієнтацій, професійних потреб, особистісних якостей, необхідних директору, щоб якісно організувати цей процес на практиці.

Опанування змістом курсу забезпечило розуміння магістрантами актуальності проблеми якості дошкільної освіти й готовності майбутніх директорів до забезпечення якості освітнього процесу в дошкільній установі, формування знань про складники внутрішньої і зовнішньої систем забезпечення якості освіти в ЗДО, критерії оцінки якості освітнього процесу, засоби забезпечення якості й оптимальні умови його організації, роль кожного члена педагогічного колективу й директора ЗДО в забезпеченні якості освітнього процесу в закладі.

Викладання курсу було побудоване на технологіях проблемного, позиційного та інтерактивного навчання. Перетворення студента на суб'єкта освітнього процесу, завдяки застосуванню означених технологій, дозволило підвищити якість і усвідомленість процесу засвоєння знань, вироблення на цій основі відповідних умінь, підготуватися до проходження практики i виконання відповідних завдань, чіткіше визначитися 3 мотивами, ціннісними орієнтаціями, особистіснопрофесійними якостями, необхідними для організації освітнього процесу в ЗДО на адміністративному рівні. Не останню роль у цьому процесі відіграли завдання для самостійної роботи магістрантів, зокрема розробка програми забезпечення якості освітнього процесу в ЗДО, створення власних критеріїв оцінки одного із видів життєвої компетентності вихованців чи професійної компетентності вихователя, розробка програми самовдосконалення директора ЗДО щодо забезпечення якості освітнього процесу в дошкільній установі.

Результати аналізу анкетування, яке провели на контрольному етапі експерименту, засвідчили позитивні зміни у сформованості показників мотиваційноособистісного компонента ГДЗЯОП магістрів експериментальної групи. Так, переважна більшість магістрантів експериментальної групи (70\%) правильно називала складники спрямованості директора ЗДО (мотиви, потреби, ціннісні орієнтації, інтереси, ідеали). Серед мотивів, які виділяли $50 \%$ респондентів, менше зустрічалося тих, які стосуються будь-якої професійної діяльності чи діяльності директора ЗДО в цілому. При цьому називали такі мотиви: перетворення ЗДО на конкурентоспроможний освітній заклад, організація освітнього процесу у відповідності до сучасних вимог держави і батьків вихованців; постійне професійне вдосконалення колективу і адміністрації закладу тощо. Серед ціннісних орієнтацій були зазначені орієнтації на суспільне визнання та позитивну оцінку роботи ЗДО, розвиток, освіченість і вихованість дітей відповідно до запитів батьків та вимог школи; збереження і зміцнення здоров'я вихованців; організацію життєдіяльності вихованців на принципах гуманізму, дитиноцентризму, суб'єкт-суб'єктної взаємодії; на створення умов для реалізації інклюзивної освіти в ЗДО; на створення оптимальних умов для роботи вихователів; на професійний ріст як директоpa, так всього педагогічного колективу закладу; на покращення матеріально-технічної бази та приведення стану ЗДО у відповідність до сучасних вимог; на відкритість до інновацій, прозорість оцінки якості освітніх послуг, які надає заклад.

Називаючи професійно-особистісні якості директоpa, необхідні для організації якісного освітнього процесу, керувалися знаннями управлінських функцій i критеріями оцінки якості дошкільної освіти, брали до уваги специфічність об'єкту професійної діяльності. Помітною була і відносна рівновага між моральними, вольовими та інтелектуальними якостями директора ЗДО, які перераховувалися в анкетах (особистісні: наполегливість, урівноваженість, доброзичливість, комунікативність, тактовність, толерантність, дисциплінованість, цілеспрямованість, креативність, гуманність; професійні: любов до професії, відповідальність, вимогливість, оперативність, відкритість до інновацій, повага до колег, об'єктивність, здатність визнавати свої помилки, самокритичність, впливовість, антиципаційність).

Таблиця 1. Рівні сформованості мотиваційно-особистісного компонента ГДЗЯОП в ЗДО на констатувальному і контрольному етапах експерименту

\begin{tabular}{|c|c|c|c|c|c|c|c|c|}
\hline Рівні & \multicolumn{2}{|c|}{ Високий } & \multicolumn{2}{|c|}{ Достатній } & \multicolumn{2}{|c|}{ Середній } & \multicolumn{2}{|c|}{ Низький } \\
\hline Етапи & I & II & I & II & I & II & I & II \\
\hline Групи & 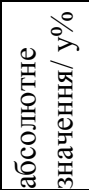 & 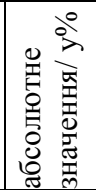 & 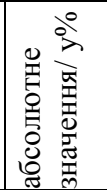 & 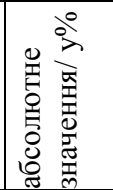 & 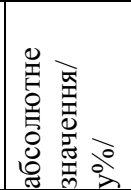 & 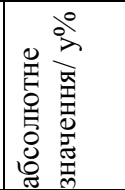 & 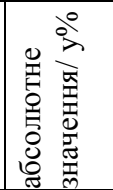 & 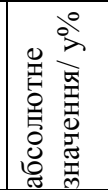 \\
\hline Контрольна & $22 / 8,1$ & $22 / 8,1$ & $67 / 24,8$ & $73 / 27$ & $135 / 50$ & $133 / 49,3$ & $46 / 17,1$ & $42 / 15,6$ \\
\hline Експериментальна & $16 / 5,8$ & $25 / 9,1$ & $53 / 19,4$ & $79 / 28,8$ & $145 / 52,9$ & $132 / 48,2$ & $60 / 21,9$ & $38 / 13,9$ \\
\hline
\end{tabular}

У контрольній групі зміни в рівнях сформованості мотиваційно-особистісного компонента ГДЗЯОП виявилися менш помітними. Результати діагностування означеного компонента готовності магістрантів експериментальної і контрольної груп на констатува- льному і контрольному етапах експерименту відображено в таблиці №1.

Висновки. Отже, результати діагностики на констатувальному i контрольному етапах експерименту засвідчили позитивну динаміку в рівнях мотиваційноособистісного компонента ГДЗЯОП майбутніх дирек- 
торів закладів дошкільної освіти. Цьому сприяло передусім вивчення магістрантами авторського інтегро- ваного курсу «Методика забезпечення якості освітнього процесу в закладі дошкільної освіти».

\section{ЛІТЕРАТУРА}

1. Вітвицька С. С. Теоретичні і методичні засади підготовки магістрів в умовах ступеневої освіти: автореф. дис. на здобуття наук. ступеня доктора пед. наук: спец. 13.00.04 - «Теорія і методика професійної освіти». Житомир. $2011.43 \mathrm{c}$.

2. Загородня Л.П. Критерії, показники та рівні сформованості готовності магістрів до забезпечення якості освітнього процесу в закладі дошкільної освіти Педагогічна освіта: теорія і практика : Зб. наук. праць. Кам'янеиь-Поділ. наи. ун-ту імені Івана Огієнка. Вип. 25. (2-2018). Ч.1. Кам'янець-Подільський, 2018. С. 65-71. DOI: 10.32626/2309-9763.2018-25.65-71.

3. Задорожна-Княгницька Л. В. Обгрунтування змісту й структури деонтологічної компетентності менеджера

освіти Journal «ScienceRise: Pedagogical Education» №2 (22) 2018. C. 24-28. DOI: 10.15587/2519-4984.2018.124456.

4. Закорченна Г. М. Підготовка студентів до педагогічного менеджменту в дошкільній освіті : автореф. дис. на здобуття наук. ступеня кандидата пед. наук: спец. 13.00.04 «Теорія і методика професійної освіти». Одеса, 2000. 24 c.

5. Жигірь В. І. Сутність і зміст професійно важливих якостей особистості менеджера освіти. Вісн. Луган. наи. ун-ту імені Тараса Шевченка. Педагогічні науки. Луганськ, 2013. № 10(3). C 113-124.

6. Шапар В. Б. Психологічний тлумачний словник. Х. : Прапор, 2004. 540 c.

\section{REFERENCES}

1. Vitvytska, S. S. (2011). Theoretical and methodological basis of training masters in a multi-level education. - author. dis. for the Sciences. degree of doctor of PED. Sciences: special. 13.00.04 - "Theory and methods of professional education". Zhytomyr, 43 p. [in Ukrainian].

2. Zahorodnia, L. P. (2018). Criteria, indicators and levels of formation of readiness of master's degrees to ensure the quality of the educational process in institutions of preschool education. - Teacher education: theory and practice : SB. Sciences. labours'. Kamianets-Podil. University named after Ivan Ohienko. Issue. 25 (2-2018). Part 1. Kamianets-Podilskyi pp. 65-71. DOI: 10.32626/2309-9763.2018-25.65-71. [in Ukrainian].

3. Zadorozhna-Kniahnytska, L. V. (2018). Substantiation of the content and structure of the deontological competence of the education Manager. Journal «ScienceRise: Pedagogical Edu-

cation» №2 (22) pp. 24-28. DOI: 10.15587/25194984.2018.124456. [in Ukrainian].

4. Zakorchenna, H. M. (2000). Students' training for pedagogical management in preschool education] avtoref. dys. na zdobuttia nauk. stupenia kandydata ped. nauk: spets. - author. dis. for the Sciences. degree of candidate of PED. Sciences: special. 13.00.04 - "Theory and methods of professional education". Odesa, 24 p. [in Ukrainian].

5. Zhyhir, V. I. (2013) The essence and content of professionally important qualities of the education Manager's personality. Visn. Lugan. nat. univ. - the name of Taras Shevchenko. Pedagogical science. Luhansk. № 10(3). pp. 113-124. [in Ukrainian].

6. Shapar, V. B. (2004) Psychological dictionary. Kh. : Prapor. 540 p. [in Ukrainian].

Formation of Motivational Component and Personal Component of Masters' Readiness to the Educational Process Quality Ensuring in the Preschool Educational Institutions

L. P. Zahorodnia

Abstract. The author presents the results of empirical research of the state of the motivational component readiness' formation and personal component readiness' formation to educational process quality ensuring in the preschool institution. The formation of pointed component of readiness in the process of the author's integrated study course studying «Methods of the Educational Process Quality Ensuring in the Preschool Institution» is briefly described.

Keywords: Masters of preschool education, motivational component and personal component of readiness to ensuring the quality of the educational process in preschool educational institutions, diagnostic methods, author's integrated study course, levels of formation. 